\title{
Headwater stream fish fauna from the Upper Paranapanema River basin
}

\author{
Mauricio Cetra ${ }^{1,5}$, George Mendes Taliaferro Mattox ${ }^{2}$, Fabio Cop Ferreira ${ }^{3}$, Rayssa Bernardi Guinato ${ }^{2}$, \\ Fernando Vieira Silva ${ }^{4}$ \& Marina Pedrosa ${ }^{2}$ \\ ${ }^{1}$ Universidade Federal de São Carlos, Departamento de Ciências Ambientais, Sorocaba, SP, Brazil. \\ ${ }^{2}$ Universidade Federal de São Carlos, Departamento de Biologia, Sorocaba, SP, Brazil. \\ ${ }^{3}$ Universidade Federal de São Paulo, Departamento de Ciências do Mar, Santos, SP, Brazil. \\ ${ }^{4}$ Universidade Federal de São Carlos, Programa de Pós-Graduação em Sustentabilidade na Gestão Ambiental, \\ Sorocaba, SP, Brazil. \\ ${ }^{5}$ Corresponding author: Mauricio Cetra, e-mail: mcetra@ufscar.br
}

CETRA M., MATTOX, G.M.T., FERREIRA, F.C., GUINATO, R.B., SILVA, F.V., PEDROSA, M. Headwater stream fish fauna from the Upper Paranapanema River basin. Biota Neotropica. 16(3): e20150145. http://dx.doi.org/10.1590/1676-0611-BN-2015-0145

\begin{abstract}
The Paraná River basin has about 600 fish species. In the Upper Paraná, 310 fish species were recorded, with 52 species were registered in the streams and headwaters of the Paranapanema River. The aim of this study was to characterize the stream fish communities in the Upper Paranapanema River basin. Samplings were conducted with electrofishing during the dry season in the year of 2014. The collection effort consisted of 30 streams stretches. As a result, 41 species of stream fish were recorded in the Upper Paranapanema River basin, distributed in 26 genera, 11 families and 7 orders. Thirty-nine percent of the species can be considered rare, $41 \%$ intermediate and $20 \%$ common. We captured approximately eight species by stream stretch and the estimated richness (Schao2) was $40 \pm 6$ species. Around $40 \%$ of the individuals had less than $50 \mathrm{~mm}$ in length.
\end{abstract}

Keywords: fish communities, estimated richness, rare species.

CETRA M., MATTOX, G.M.T., FERREIRA, F.C., GUINATO, R.B., SILVA, F.V., PEDROSA, M. Ictiofauna de riachos das cabeceiras da bacia hidrográfica do Alto Paranapanema. Biota Neotropica. 16(3): e20150145. http://dx.doi.org/10.1590/1676-0611-BN-2015-0145

Resumo: A bacia hidrográfica do Rio Paraná possui cerca de 600 espécies de peixes. No Alto Rio Paraná, 310 espécies de peixes foram registradas com 52 espécies registradas em riachos do Rio Paranapanema. O objetivo deste estudo foi caracterizar a comunidade de peixes de riachos da bacia do Alto Rio Paranapanema. O levantamento das espécies foi realizado com uso de pesca elétrica durante a estação seca de 2014. As coletas ocorreram em 30 trechos de riachos. Foram capturas 41 espécies distribuídas em 26 gêneros, 11 famílias e 7 ordens. Trinta e nove por cento das espécies podem ser consideradas raras, $41 \%$ intermediárias e $20 \%$ comuns. Foram capturadas cerca de 8 espécies por trecho de riacho e a riqueza estimada (Schao2) foi $40 \pm 6$ espécies. Cerca de $40 \%$ dos indivíduos possuem comprimento menor que $50 \mathrm{~mm}$.

Palavras-chave: comunidades de peixes, riqueza estimada, espécies raras. 


\section{Introduction}

The Paraná River basin is the second largest in area in the Neotropical region (Agostinho \& Júlio Jr. 1999), with about 2.6 million $\mathrm{km}^{2}$. Older estimates suggest that this basin has nearly 600 fish species (Bonetto 1986). Recently, 310 fish species were recorded in the Upper Paraná (Langeani et al. 2007), which comprises approximately 900,000 $\mathrm{km}^{2}$ and the portion of this basin in São Paulo State includes 260 species along the Paraná River and its main tributaries, Paranapanema, Tietê and Grande (Oyakawa \& Menezes 2011). About 65\% of these species were small sized (less than $21 \mathrm{~cm}$ ), and occurred in streams and headwaters (Langeani et al. 2007). Recent inventories documented a high diversity fish fauna for the Upper Paraná (Casatti et al. 2001, Castro \& Casatti 1997, Castro et al. 2003, 2004, 2005, Langeani et al. 2005a b, Fagundes et al. 2015).

As recommended by Casatti et al. (2008), this study intended to perform the following actions:

(i) survey the fish populations in the Upper Paranapanema River basin, which currently presents a knowledge gap;

(ii) study the fish community from streams and headwaters that are especially interesting for sharing species with neighboring basins;

(iii) provide information on the fish populations that can be used in the monitoring of riparian forests restoration projects.

This study aimed to characterize the stream fish communities in the Upper Paranapanema River and supplement the species lists of Castro et al. (2003).

\section{Material and Methods}

\section{Study area}

The Upper Paranapanema River basin is located in the Unidade de Gerenciamento dos Recursos Hídricos [Water Resources Management Unit] (UGRHI 14). This unit presents agriculture activity and population density around 30 inhabitants $/ \mathrm{km}^{2}$. About $15 \%$ of the area is covered by native vegetation, and the headwaters are covered by reforested area (Eucaliptus spp.) and native forests (CETEC 1999). The headwater streams are in the Serra de Paranapiacaba, at about $1100 \mathrm{~m}$ altitude, and are tributaries of the Paranapanema River, which, after running along $500 \mathrm{~km}$, will flow into the Paraná River.

\section{Fish Sampling}

Fish sampling was conducted from June to November 2014 as the associations between fish assemblage and environmental structure are better described in the dry season (Pinto et al. 2006). Furthermore, it is important to control the effect of sources of temporal variation.

The ichthyofauna sampling was performed with electrofishing between $10 \mathrm{~h}$ and $16 \mathrm{~h}$ (License SISBIO 13352-1/IBAMA/MMA). We collected the fish fauna in 30 streams stretches with $70 \mathrm{~m}$. These streams are located in 13 watersheds in the municipalities of Piedade, Pilar do Sul, São Miguel Arcanjo, Capão Bonito, Ribeirão Grande, Guapiara, Apiaí, Ribeirão Branco, Itapeva, Itaberá, Itararé and Sengés (Figure 1, Table 1), covering stretches of $1^{\text {st }}$ to $6^{\text {th }}$ orders (Hydrology ArcGIS software tool).
The wadeable stream stretches have at least one sequence of rifflerun-pool meso-habitats. The organisms collected were fixed for $48 \mathrm{~h}$ in $4 \%$ formalin and then transferred to $70 \%$ alcohol. Vouchers of the species collected were deposited in the collection of Laboratório de Ictiologia of the Departamento de Zoologia e Botânica da UNESP São José do Rio Preto (DZSJRP 20.268 - 20.663) and of Laboratório de Ictiologia de Ribeirão Preto - FFCLRP/USP (LIRP 11826). The specimens were identified according to Castro et al. (2003), Castro \& Vari (2004), Vari \& Castro (2007), Lucinda (2008), Zawadzki et al. (2008), Lippert et al. (2014) and with the assistance of specialists in some groups.

\section{Results and Discussion}

We captured about $7 \mathrm{~kg}$ of fish: 1878 individuals, 41 species, 26 genera, 11 families and 7 orders (Table 2). Following the criteria of Teshima et al. (2015), 16 species (39\%) can be considered rare, 17 species (41\%) are intermediate and 7 species $(20 \%)$ are common. On average, we captured approximately 8 species by stream stretch and the estimated richness (Schao2) was $40 \pm 6$ species. Around $40 \%$ of individuals had less than $50 \mathrm{~mm}$ in length.

The orders Siluriformes and Characiformes represented the majority of the species richness, $44 \%$ and $37 \%$ respectively, reflecting a well-known pattern recognized for South American rivers (LoweMcConnell 1999). Twelve species are not on the list of species that occur in the Upper Paraná (Langeani et al. 2007), and 18 are not in the list by Castro et al. (2003) that collected fish in streams of the Paranapanema basin.

Some species have been listed with different names as presented in Castro et al. (2003) and Langeani et al. (2007) (Table 2, with asterisk). This happened because some species that had been recognized as distinct morphotypes were later formally described. This is the case of Astyanax sp1 and Astyanax sp2 (Castro et al. 2003), later described as A. bockmanni and A. biotae (Castro \& Vari 2004, Vari \& Castro 2007). A Bryconamericus morphotype with humeral spot was identified only at the genus level (Castro et al. 2003). Langeani et al. (2007) identified a morphotype of Bryconamericus with humeral spot as B. iheringii, highlightening that this could probably represent a new species. Also, these previous lists included Phalloceros caudimaculatus as a single species, but we found herein both species currently recognized in the genus for the Paranapanema basin (see below).

The São Paulo State fish fauna is relatively well known (Langeani et al. 2007, Oyakawa \& Menezes 2011). However, there are still many taxa to be better studied and that probably represent new species. It is known, for instance, that Astyanax scabripinnis represents a group of species, some of which still undescribed, and further detailed analysis based on larger and more complete sample series may result in the description new species (e.g., Moreira-Filho \& Bertollo 1991, Bertaco \& Malabarba 2001, Bertaco \& Lucena 2006, Fagundes et al. 2015).

Neoplecostomus selenae, Phalloceros reisi and P. harpagos were described in 2008 but were already cited as new species under description by Langeani et al. (2007). Otothyropsis biamnicus was recently described (Calegari et al. 2013) and included in a recent species list of the Upper Paraná (Fagundes et al. 2015). 


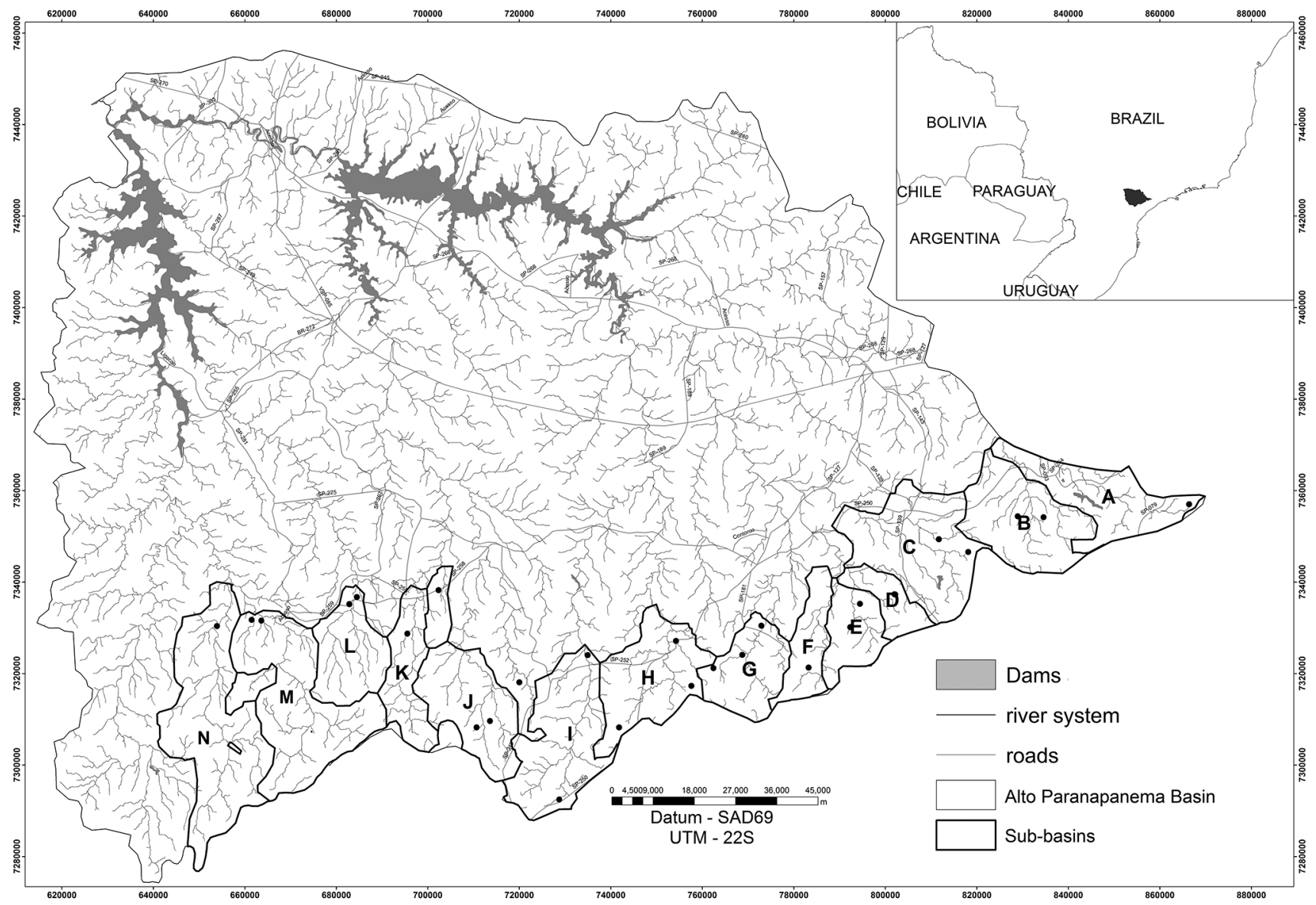

Figure 1. Sub-basins and stretch streams sampled: A (Turvo), B (Pinhal), C (Guarapú), D (Taquaral), E (Guapiara), F (Paranapanema), G (Almas), H (Apiaí-Mirim), I (Apiaí-Guaçu), J (Taquari-Guaçu), K (Pirituba), L (Verde), M (Itararé), N (Jaguaricatu).

Table 1. Geographical information of the stretch streams sampled.

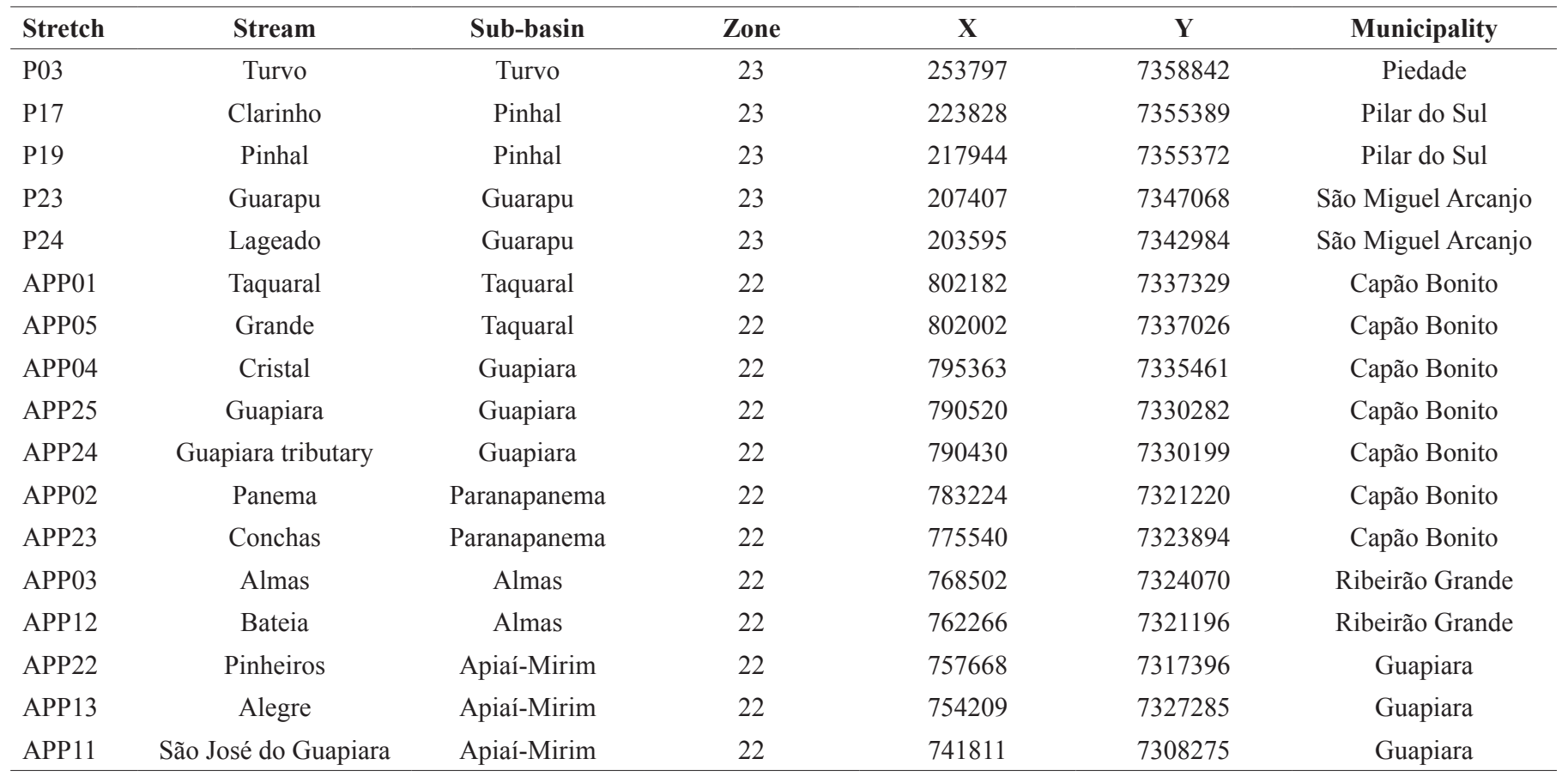


Cetra, M. et al.

Continued Table 1.

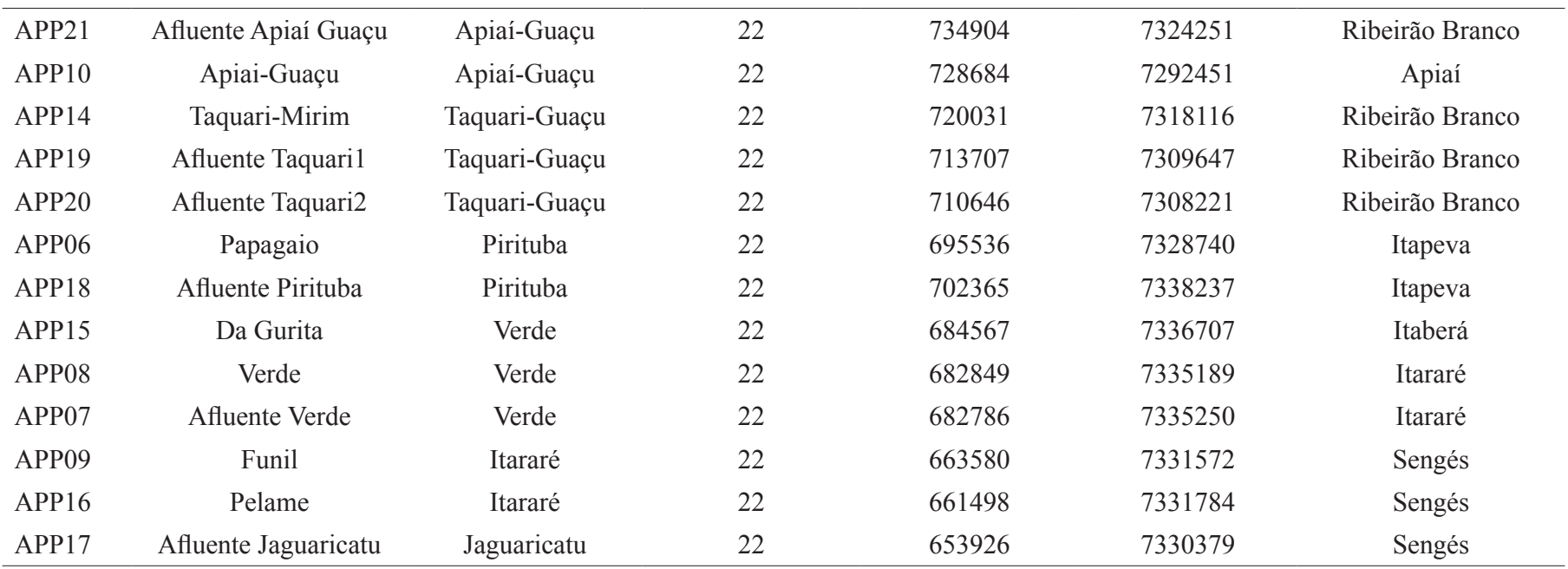

Table 2. Species sampled in the headwater streams from Upper Paranapanema River basin with respective status. X: species listed in Castro et al. (2003) and/or Langeani et al. (2007). Asterisk indicates species listed with a different name in previous papers.

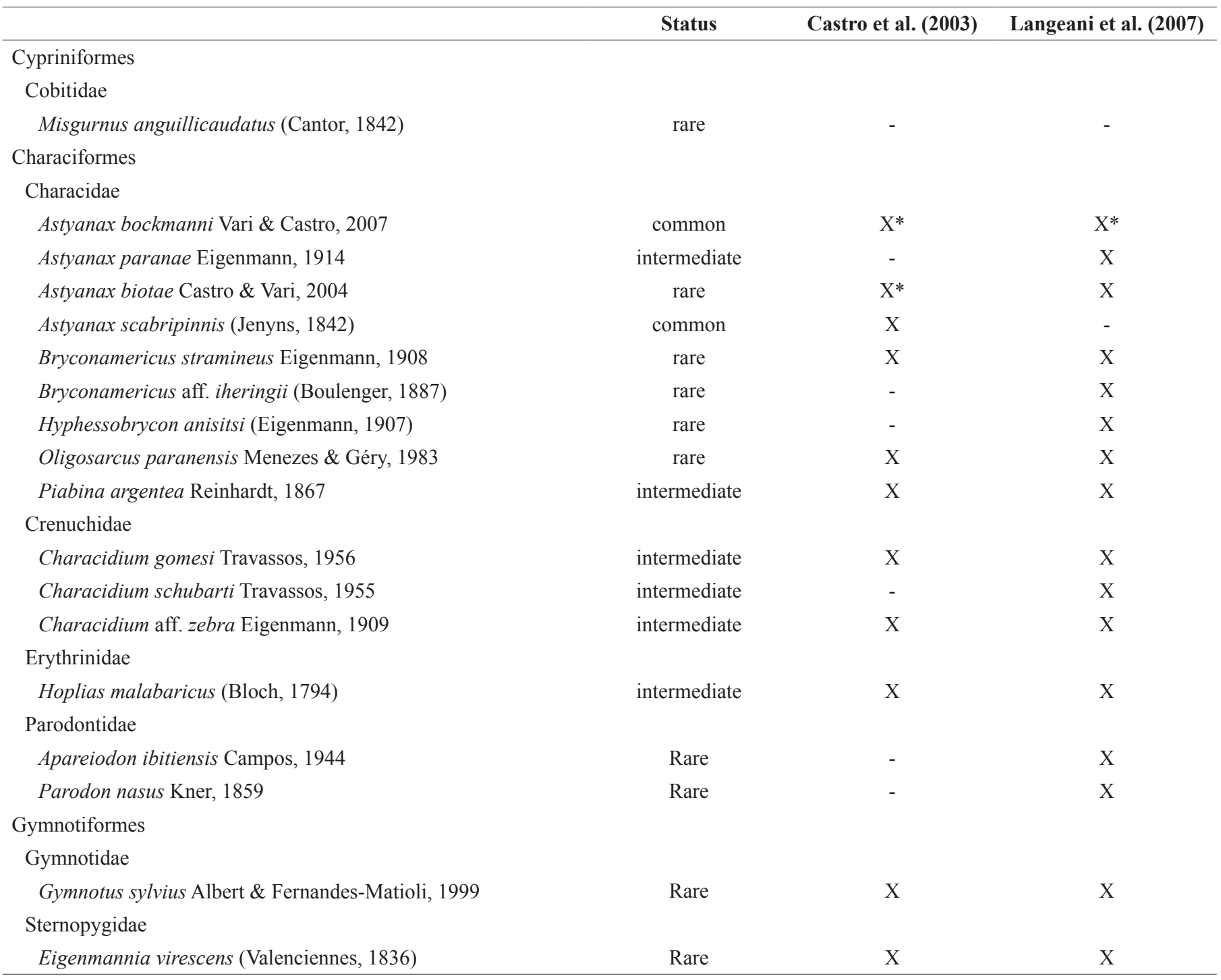


Continued Table 2.

\section{Siluriformes}

Heptapteridae

Cetopsorhamdia iheringi Schubart \& Gomes, 1959

Imparfinis borodini Mees \& Cala, 1989

Imparfinis mirini Haseman, 1911

Phenacorhamdia tenebrosa (Schubart, 1964)

Pimelodella avanhandavae Eigenmann, 1917

Rhamdia quelen (Quoy \& Gaimard, 1824)

Loricariidae

Hypostomus ancistroides (Ihering, 1911)

Hypostomus nigromaculatus (Schubart, 1964)

Hypostomus sp1

Hypostomus $\mathrm{sp} 2$

Neoplecostomus selenae Zawadzki, Pavanelli \& Langeani, 2008

Otothyropsis biamnicus Calegari, Lehmann \& Reis, 2013

Otothyropsis sp.

Rineloricaria pentamaculata Langeani \& Araújo, 1994

Trichomycteridae

Trichomycterus davisi (Haseman, 1911)

Trichomycterus diabolus Bockmann, Casatti \& de Pinna, 2004

Trichomycterus $\mathrm{sp} 1$

Trichomycterus $\mathrm{sp} 2$

Cyprinodontiformes

Poecilidae

Poecilia vivipara Bloch \& Schneider, 1801

Phalloceros reisi Lucinda, 2008

Phalloceros harpagos Lucinda, 2008

Synbranchiformes

Synbranchidae

Synbranchus marmoratus Bloch, 1795

Labriformes

Cichlidae

Geophagus brasiliensis (Quoy \& Gaimard, 1824)

The species mentioned above were described in the last 10 years, hence discovered in relative recent times. In addition, some taxa could not be identified to species level, probably because they represent new taxa awaiting description. As noted by Langeani et al. (2007), this may be the case of Hypostomus sp1, Hypostomus sp2, Trichomycterus sp1, Trichomycterus sp2 and Othothyropsis sp, which should contribute to the increase in the species richness from the Upper Paraná.

The exotic species Misgurnus anguillicaudatus had been registered in the Iguaçu River basin (Ingenito et al. 2004, Vitule 2009) and was recently captured in preserved streams in the Ribeira de Iguape River basin (Gomes et al. 2011, Cetra et al. 2012). We herein present the first record of this species in the Paranapanema River basin in the São Paulo State.

Among the 41 fish species sampled in the present study, we highlight Neoplecostomus selenae, a species listed as vulnerable on the list of endangered species in São Paulo State (Oyakawa et al. 2009). This

\begin{tabular}{|c|c|c|}
\hline Intermediate & $\mathrm{X}$ & $\mathrm{X}$ \\
\hline intermediate & - & $\mathrm{X}$ \\
\hline Common & $\mathrm{X}$ & $\mathrm{X}$ \\
\hline Rare & $\mathrm{X}$ & $\mathrm{X}$ \\
\hline Common & - & $\mathrm{X}$ \\
\hline intermediate & $\mathrm{X}$ & $\mathrm{X}$ \\
\hline Common & $\mathrm{X}$ & $\mathrm{X}$ \\
\hline intermediate & $\mathrm{X}$ & $\mathrm{X}$ \\
\hline Rare & - & - \\
\hline Intermediate & - & - \\
\hline Common & - & - \\
\hline Rare & - & - \\
\hline Rare & - & - \\
\hline intermediate & $\mathrm{X}$ & $\mathrm{X}$ \\
\hline intermediate & - & - \\
\hline Rare & - & $\mathrm{X}$ \\
\hline intermediate & - & - \\
\hline intermediate & - & - \\
\hline Rare & - & $\mathrm{X}$ \\
\hline Common & $*$ & $*$ \\
\hline intermediate & $*$ & * \\
\hline intermediate & $\mathrm{X}$ & $\mathrm{X}$ \\
\hline Common & $\mathrm{X}$ & $\mathrm{X}$ \\
\hline
\end{tabular}

species was included in that list because it was known solely from the type locality in Ribeirão das Bateias basin, Ribeirão Grande municipality (Zawadzki et al 2008). For the conservation of this species, Oyakawa et al. (2009) suggested habitat protection and scientific research to obtain data on its biology, and inventories to better access the distribution of this species. The results in the present study expanded the area of occurrence of N. selenae (Apiaí-Guaçu, Apiaí-Mirim, Guapiara, Itararé, Panema, Taquaral, Taquari-Guaçu and Verde sub-basins) yielding new specimens for further studies.

The present study complemented data on fish populations of the Upper Paraná River basin, specifically of the tributary streams of the Paranapanema River (e.g., Castro et al. 2003, Langeani et al. 2007), representing a considerable increase in the richness in the latter drainage, in addition to a few putative new species. Although the fish fauna of the Paraná River basin is relativelky well known (eg, Langeani et al. 2007, Oyakawa 
\& Menezes 2011), several areas of this drainage system still remain unexplored and represent gaps in the knowledge of this ichthyofauna.

\section{Acknowledgements}

The species identification had the valuable assistance of Bárbara Calegari, Fernanda Martins, Flávio Bockmann, Paulo Lucinda, Veronica Slobodian, who sent appropriate literature and/or examined specimens. This study was financed by FAPESP - Proc. No. 2013/24737-2.

\section{References}

AgOSTINHO, A.A. \& JÚLIO JR., H.F. 1999. Peixes da Bacia do Alto Rio Paraná. In Estudos Ecológicos de Comunidades de Peixes Tropicais (R.H. Lowe-McConnell). EDUSP, São Paulo, p.374-400.

BERTACO, V.A. \& LUCENA, C.A.S. 2006. Two new species of Astyanax (Ostariophysi: Characiformes: Characidae) from eastern Brazil, with a synopsis of the Astyanax scabripinnis complex. Neotrop. Ichthyol. 4(1):53-60.

BERTACO, V.A. \& MALABARBA, L.R. 2001. Description of new species of Astyanax (Teleostei: Characidae) from headwater streams of Southern Brazil, with comments on the "A. scabripinnis species complex". Ichthyol. Explor. Freshwaters, 12(3):221-234.

BONETTO, A.A. 1986. The Paraná River System. In The ecology of river systems (B.R. Davies \& K.F. Walker, eds). Dr. Junk Publisher, The Hague, p.541-556

CALEGARI, B.B., LEHMANN, P. \& REIS, R. 2013. Two new species of cascudinhos of the genus Otothyropsis (Siluriformes: Hypoptopomatinae) from the rio Paraná basin, Brazil. Zootaxa 3619(2):130-144.

CASATTI, L., LANGEANI, F. \& CASTRO, R.M.C. 2001. Peixes de riacho do Parque Estadual Morro do Diabo, bacia do Alto Rio Paraná, SP. Biota Neotrop. 1(1/2):1-15. http://www.biotaneotropica.org.br/v1n12/pt/abstract ?inventory+BN00201122001.

CASATTI, L., LANGEANI, F., MENEZES, N.A., OYAKAWA, O.T. \& BRAGA, F.M.S. 2008. Peixes de água doce. In: Rodrigues, R.R., Bononi, V.L.R. (Orgs). Diretrizes para conservação e restauração da biodiversidade no estado de São Paulo. 1 ed. São Paulo: Instituto de Botânica, v.1, p. 95-98.

CASTRO, R.M.C. \& CASATTI, L. 1997. The fish fauna from a small forest stream of the upper Paraná River Basin, southeastern Brazil. Ichthyol. Explor. Freshwaters 7:337-352.

CASTRO, R.M.C., CASATTI, L., SANTOS, H.F., FERREIRA, K.M., RIBEIRO, A.C., BENINE, R.C., DARDIS, G.Z.P., MELO, A.L.A., ABREU, T.X., BOCKMANN, F.A., CARVALHO, M., GIBRAN, F.Z. \& LIMA, F.C.T. 2003. Estrutura e composição da ictiofauna de riachos do Rio Paranapanema, sudeste e sul do Brasil. Biota Neotrop. 3(1):1-31. http:// www.biotaneotropica.org.br/v3n1/pt/abstract?article+BN01703012003.

CASTRO, R.M.C. \& Vari, R.P. 2004. Astyanax biotae, a new species of stream fish from the Rio Paranapanema basin, upper Rio Paraná system, southeastern Brazil (Ostariophysi: Characiformes: Characidae). Proc. Biolo. Soc. Wash. 117(3):330-338

CASTRO, R.M.C., CASATTI, L., SANTOS, H.F., MELO, A.L.A., MARTINS, L.S.F., FERREIRA, K.M., GIBRAN, F.Z., BENINE, R.C., CARVALHO, M., RIBEIRO, A.C., ABREU, T.X., BOCKMANN, F.A., DARDIS, G.Z.P., STOPIGLIA, R. \& LANGEANI, F. 2004. Estrutura e composição da ictiofauna de riachos da bacia do Rio Grande, no Estado de São Paulo, Sudeste do Brasil. Biota Neotrop. 4(1):1-39. http://www.biotaneotropica. org.br/v4n1/pt/abstract?article+BN0170402004

CASTRO, R.M.C., CASATTI, L., SANTOS, H.F., VARI, R.P., MELO, A.L.A., MARTINS, L.S.F., ABREU, T.X., BENINE, R.C., GIBRAN, F.Z., RIBEIRO, A.C., BOCKMANN, F.A., CARVALHO, M., PELIÇÃO, G.Z., FERREIRA, K.M., STOPIGLIA, R. \& AKAMA, A. 2005. Structure and composition of the stream ichthyofauna of four tributary rivers of the upper Rio Paraná basin, Brazil. Ichthyol. Explor. Freshwaters 16(3):193-214.

CETEC - CENTRO TECNOLÓGICO DA FUNDAÇÃO PAULISTA DE TECNOLOGIA E EDUCAÇÃO. 1999. Situação dos recursos hídricos do Alto Paranapanema UGRHI 14 - Minuta Preliminar do Relatório Técnico Final. 317 pp. Disponível em: http://www.sigrh.sp.gov.br/cgi-bin/sigrh_home colegiado.exe?COLEGIADO=CRH\%2FCBH-RB\&TEMA=RELATORIO.
CETRA, M., BARRELlA, W., LANGEANI, F., MARTINS, A.G., MELLO, B.J. \& ALMEIDA, R.S. 2012. Fish fauna of headwater streams that cross the Atlantic Forest of South São Paulo state. Check List 8(3):421-425.

FAGUNDES, D.C., LEAL, C.G., CARVALHO, D.R., JUNQUEIRA, N.T., LANGEANI, F. \& POMPEU, P.S. 2015. The stream fish fauna from three regions of the Upper Paraná River basin. Biota Neotrop. 15(2):1-8. http://www.scielo.br/scielo.php?script=sci_arttext\&pid=S167606032015000200203\&lng $=$ pt\&nrm=iso.

GOMES, C.I.D.A., PERESSIN, A., CETRA, M. \& BARRELLA, W. 2011. First adult record of Misgurnus anguillicaudatus Cantor 1842 from Ribeira de Iguape River Basin, Brazil. Acta Limnol. Bras. 23(3):229-232.

INGENITO, L.F.S., DUBOC, L.F. \& ABILHOA, V. 2004. Contribuição ao conhecimento da ictiofauna da bacia do alto rio Iguaçu, Paraná, Brasil. Arq. Ciênc. Vet. Zool. UNIPAR 7(1):23-36.

LANGEANI, F., CASATTI, L., GAMEIRO, H.S., BELLUCCO-DO-CARMO, A. \& ROSSA-FERES, D.C. 2005a. Riffle and pool fish communities in a large stream of southeastern Brazil. Neotrop. Ichthyol. 3(2):305-311.

LANGEANI, F., LUCENA, Z.M.S., PEDRINI, J. \& TARELHO-PEREIRA, F.J. 2005b. Bryconamericus turiuba, a new species from the upper rio Paraná system (Ostariophysi: Characiformes). Copeia 2005(2):386 392.

LANGEANI, F., CASTRO, R.M.C., OYAKAWA, O.T., SHIBATTA, O.A., PAVANELLI, C.S. \& CASATTI, L. 2007. Diversidade da ictiofauna do Alto Rio Paraná: composição atual e perspectivas futuras. Biota Neotrop. 7(3):181-197. http://www.biotaneotropica.org.br/v7n3/pt/ abstract?article+bn03407032007.

LIPPERT, B.G., CALEGARI, B.B. \& REIS, R.E. 2014. A new species of Otothyropsis (Siluriformes: Hypoptopomatinae) from Eastern Brazil. Copeia 2014(2):238-244.

LOWE-MCCONNELL, R. 1999. Estudos Ecológicos de Comunidades de Peixes Tropicais. EDUSP, São Paulo.

LUCINDA, P.H.F. 2008. Systematics and biogeography of the genus Phalloceros Eigenmann, 1907 (Cyprinodontiformes: Poeciliidae: Poeciliinae), with the description of twenty-one new species. Neotrop. Ichthyol. 6(2):113-158.

MOREIRA-FILHO, O. \& BERTOLLO, L.A.C.. 1991. Astyanax scabripinnis (Pisces, Characidae): a species complex. Rev. Bras. Genética 14: 331-357.

OYAKAWA, O.T. \& MENEZES, N.A. 2011. Checklist dos peixes de água doce do Estado de São Paulo. Biota Neotrop. 11(Supl. 1):19-31. http://www. biotaneotropica.org.br/v11n1a/en/abstract?inventory+bn0021101a2011.

OYAKAWA, O.T., MENEZES, N.A., SHIBATTA, O.S., LIMA, F.C.T., LANGEANI, F., PAVANELLI, C.S., NIELSEN, D.T.B. \& HILSDORF, A.W.S. 2009. Peixes de água doce. In Fauna ameaçada de extinção no Estado de São Paulo: Vertebrados (P.M. Bressan, M.C.M. Kierulff \& A.M. Sugieda, orgs).Secretaria do Meio Ambiente, São Paulo, p.349-424.

PINTO, P., MORAIS, M., ILHÉU, M., SANDÍN, L. 2006. Relationships among biological elements (macrophytes, macroinvertebrates and ichthyofauna) for different core river types across Europe at two different spatial scales. Hydrobiologia, 566(1): 75-90.

TESHIMA, F.A., FERREIRA, F.C. \& CETRA, M. 2015. Rarity status of endemic and vulnerable fish species in a Brazilian Atlantic Forest protected area. Natureza \& Conservação 13:67-73.

VARI, R.P. \& CASTRO, R.M.C. 2007. New species of Astyanax (Ostariophysi: Characiformes: Characidae) from the Upper Rio Paraná System, Brazil. Copeia 2007(1):150-162.

VITULE, J.R.S. 2009. Introdução de peixes em ecossistemas continentais brasileiros: revisão, comentários e sugestões de ações contra o inimigo quase invisível. Neotrop. Biol. Conserv. 4(2):111-122.

ZAWADZKI, C.H., PAVANELLI, C.S. \& LANGEANI, F. 2008. Neoplecostomus (Teleostei: Loricariidae) from the upper Rio Paraná basin, Brazil, with description of three new species. Zootaxa 1757:31-48. 